\title{
ORGANIC ACID ADSORPTION AND MINERALIZATION IN OXISOLS WITH DIFFERENT TEXTURES ${ }^{(1)}$
}

\author{
Felipe Vaz Andrade ${ }^{(2)}$, Eduardo de Sá Mendonça ${ }^{(2)}$ \& Ivo Ribeiro da Silva ${ }^{(3)}$
}

\begin{abstract}
SUMMARY
Organic acids play an important role in the nutritional conditions of plants. Their relevance is related to their formation dynamics, mineralization rate and adsorption by soil colloids. This study was carried out to evaluate the dynamics of mineralization and adsorption of organic acid (acetic acid - AA, citric acid - CA and humic acid - HA) applied to the soil. Samples of two Oxisols were used: Rhodic Haplustox (LV) and Typic Haplustox (LVA). The mineralization experiment was arranged in a $2 \times 3 \times 5$ factorial design, based on the factors: two soils (LV and LVA) $x$ three organic acid (OA) types (AA, CA and HA) $x$ five OA rates $(0,1,2,4$, and $8 \mathrm{mmol} \mathrm{dm}^{-3}$ ). Organic carbon mineralization in samples was measured by the $\mathrm{C}_{-} \mathrm{CO}_{2}$ efflux, produced by the microbial activity, in a 30-day (measurements after $4,8,12,21$, and 30 days) and in a 4-day experiment (measured after $24,48,72$ and $96 \mathrm{~h})$. Organic acid adsorption was tested in a $2 \times 2 \times 5 \times 4$ factorial design, with the factors and levels: two Oxisols; two organic acids (AA and CA); five OA rates $(0,1,2,4$, and $8 \mathrm{mmol} \mathrm{dm}^{-3}$ ) and four adsorption periods $(6,24,48$, and $72 \mathrm{~h})$. The $\mathrm{C}-\mathrm{CO}_{2}$ production of soil treated with CA was highest. In the adsorption experiment, the affinity of CA to soil adsorption sites was greatest. The adsorption of organic acids to soils may be an important mechanism by which bioavailability and thus mineralization capacity by microbial activity are reduced.
\end{abstract}

Index terms: citric acid, humic acids, sorption, biodegradation.

\section{RESUMO: ADSORÇÃO E MINERALIZAÇÃO DE ÁCIDOS ORGÂNICOS EM LATOSSOLOS COM DIFERENTES TEXTURAS}

Os ácidos orgânicos desempenham papel importante na melhoria das condições nutricionais das plantas. A eficiência desses ácidos é condicionada pela sua taxa de mineralização e adsorção por coloides do solo. Este trabalho foi conduzido com o objetivo de

\footnotetext{
(1) Part of the Doctoral thesis of the first author at Universidade Federal de Viçosa - UFV. Received for publication on November 7, 2012 and approved on April 15, 2013.

(2) Professor, Universidade Federal do Espírito Santo - UFES, Departamento de Produção Vegetal. Alto Universitário s/n. P. O. Box 16. CEP 29500-000 Alegre (ES). E-mail: felipe.andrade@ufes.br; esmjplia@gmail.com

(3) Professor, Soil Departament, UFV. Av. P.H. Rolfs, s/n. CEP 36570-000 Viçosa (MG). E-mail: ivosilva@ufv.br
} 
avaliar o efeito da mineralização e da adsorção na dinâmica de ácidos orgânicos (ácido acético, cítrico e húmicos) adicionados ao solo. Foram utilizadas amostras de Latossolo Vermelho textura muito argilosa (LV) e Latossolo Vermelho-Amarelo textura franco-argiloarenosa (LVA). Os experimentos de mineralização seguiram esquema fatorial $2 \times 3 \times 5$, em que os fatores em estudos foram, respectivamente: dois solos (LVe LVA) x três ácidos (acido cítrico - AC, ácido acético - AA e ácidos húmicos - AH) $x$ cinco doses. A quantificação do carbono mineralizável foi realizada por meio da evolução de $\mathrm{CO}_{2}$ produzido pela atividade microbiana, para os períodos de 4, 8, 12, 21 e 30 dias (experimento de 30 dias) e 24, 48, 72 e $96 \mathrm{~h}$ (experimento de quatro dias). O experimento de adsorção seguiu esquema fatorial $2 \times 2 \times 5 \times 4$, em que os fatores em estudos foram, respectivamente: solos (LV e LVA) xácidos (ácido cítrico $A C$, ácido acético) $x$ doses $\left(0,1,2,4\right.$ e $\left.8 \mathrm{mmol} \mathrm{dm}^{-3}\right) x$ período de incubação $(6,24,48$ e $72 \mathrm{~h}$ ). $O A C$ promoveu maior quantidade de $\mathrm{CO}_{2}$ produzida, seguido do $\mathrm{AA}$ e $\mathrm{AH}$. As diferenças de labilidades entre os ácidos foram mais evidentes para o experimento de curta duração, o que reflete a dinâmica desses ácidos no solo. Para o experimento de adsorção, o AC apresentou maior afinidade pelos sítios de adsorção. A adsorção dos ácidos orgânicos pela fração mineral do solo pode tornar-se importante mecanismo em que a biodisponibilidade e a capacidade de biodegradação pela atividade microbiana podem ser reduzidas.

Termos de indexação: ácido cítrico, ácidos húmicos, sorção, biodegradação.

\section{INTRODUCTION}

Organic acids of low molecular weight (LOAs) such as malic, citric, acetic, and oxalic acids are directly involved in a number of soil processes, such as podzolization (Lundstrom et al., 2000), reduction of aluminum toxicity (Jones, 1998; Silva et al., 2001; Jones et al., 2003) and increase in nutrient availability, e.g., P (Gahoonia et al., 2000; Andrade et al., 2003), $\mathrm{Ca}$ and $\mathrm{Mg}$ (Jones \& Brassington, 1998), and $\mathrm{Mn}$ and $\mathrm{Fe}$ (Jones, 1998).

The LOAs also constitute an important source of labile C for microorganisms (Boudot, 1992; Jones \& Darrah, 1994; van Hees et al., 2002), and can increase the microbial biomass (Strom et al., 2001) and reduce its average residence time in the soil. With a half-life time of 0.5 to $12 \mathrm{~h}$, the LOAs are quickly degraded in the soil (van Hees et al., 2005). The mineralization rate is however affected by several factors, e.g., the readiness of decomposition (Jones \& Edwards, 1998), organometallic complex formations (Marschner \& Kalbitz, 2003) and soil adsorption reactions (van Hees et al., 2002). Adsorption significantly reduces LOA decomposition (Boudot, 1992; Jones \& Edwards, 1998), and is considered one of the most important stabilization processes of these acid compounds in the soil (Marschner \& Kalbitz, 2003).

The mineralization of the organic compounds that are either found in the soil or applied to it may be estimated by simple methods. Usually, the respiration rate or microbial activity is determined by the $\mathrm{C}-\mathrm{CO}_{2}$ production from aerobic microbial respiration (Kennedy \& Smith, 1995). The quality of the organic compounds added to the soil has great influence on mineralization. Aside from the physical and chemical soil properties, other characteristics related to the microbial community and its growth rate may also interact, increasing the variability of measurements (Raich \& Tufekcioglu, 2000).
In this sense, the function of LOAs in these processes is not easily measured since several factors affect their concentration in the soil, leading to an underestimation of the effects. In addition, mineralization may be reduced by the physically restricted access to the substratum, e.g., by the prevention of microbial access to LOAs due to very small pores, or the presence of stable aggregates and low moisture, affecting LOA transportation (Marschner \& Kalbitz, 2003). This study was carried out to evaluate the effects of mineralization and adsorption on the dynamics of organic acids in two Oxisols with different textures.

\section{MATERIAL AND METHODS}

Soil samples from the surface $(0-20 \mathrm{~cm})$ of a Rhodic Haplustox (LV) and a Typic Haplustox (LVA) were used (Table 1). The samples were air-dried and then passed through a $2 \mathrm{~mm}$ sieve. The samples were stored in plastic bags and limed (Ca:Mg, molar ratio 4:1). The carbonate rates were estimated to neutralize $\mathrm{Al}^{3+}$ and increase $\mathrm{Ca}^{2+}$ and $\mathrm{Mg}^{2+}$ (Alvarez V. \& Ribeiro, 1999). Soil moisture was adjusted to $60 \%$ of the field capacity. After 15 days of incubation in plastic bags, the soils were air-dried and sieved $(1 \mathrm{~mm})$.

Soil samples were separated into $50 \mathrm{~g}$ subsamples, filled in plastic pots with lids, and the treatments applied according to each assay. The soil water content was raised to $60 \%$ of the field capacity, with the application of solutions containing the macronutrient $\left(\mathrm{P}(\mathrm{LVA})=50 \mathrm{mg} \mathrm{dm}^{-3} ; \mathrm{P}(\mathrm{LV})=\right.$ $100 \mathrm{mg} \mathrm{dm}^{-3} ; \mathrm{N}=100 \mathrm{mg} \mathrm{dm}{ }^{-3} ; \mathrm{K}=125 \mathrm{mg} \mathrm{dm}^{-3}$; $\mathrm{S}=65 \mathrm{mg} \mathrm{dm}^{-3}$ ) (Andrade et al., 2007) together with rates of $0,1,2,4$, and $8 \mathrm{mmol} \mathrm{dm}^{-3}$ of each organic acids (acetic acid - AA; citric acid - CA) Andrade et al., 2007). Since humic acids are polymers with 
Table 1. Physical and chemical properties of a Rhodic Haplustox (LV) and a Typic Haplustox (LVA)

\begin{tabular}{lrr}
\hline Property & LV & LVA \\
\hline Clay $\left(\mathrm{g} \mathrm{kg}^{-1}\right)$ & 730 & 190 \\
Silt $\left(\mathrm{g} \mathrm{kg}^{-1}\right)$ & 110 & 70 \\
Sand $\left(\mathrm{g} \mathrm{kg}^{-1}\right)$ & 160 & 740 \\
Organic C $\left(\mathrm{g} \mathrm{kg}^{-1}\right)^{(1)}$ & 45 & 12 \\
$\mathrm{pH}\left(\mathrm{H}_{2} \mathrm{O}\right)(1: 2.5)$ & 5.7 & 4.8 \\
$\mathrm{Ca}^{2+}\left(\mathrm{cmol}_{\mathrm{c}} \mathrm{dm}^{-3}\right)^{(2)}$ & 3.09 & 0.37 \\
$\mathrm{Mg}^{2+}\left(\mathrm{cmol}_{\mathrm{c}} \mathrm{dm}^{-3}\right)^{(2)}$ & 0.54 & 0.09 \\
$\mathrm{~K}^{+}\left(\mathrm{mg} \mathrm{dm}^{-3}\right)^{(3)}$ & 99 & 29 \\
$\mathrm{P}\left(\mathrm{mg} \mathrm{dm}^{-3}\right)^{(3)}$ & 3.1 & 0.6 \\
$\mathrm{P}-\mathrm{rem}\left(\mathrm{mg} \mathrm{L}^{-1}\right)^{(4)}$ & 11.0 & 25.6 \\
$\mathrm{P} \mathrm{sorption}\left(\mathrm{mg} \mathrm{cm}^{-3}\right)^{(4)}$ & 1.2 & 0.7 \\
\hline
\end{tabular}

(1) Yeomans \& Bremner (1988); ${ }^{(2)}$ Extraction with $\mathrm{KCl} 1 \mathrm{~mol} \mathrm{~L}^{-1}$; (3) Extraction with Mehlich-1; ${ }^{(4)}$ Equilibrium phosphorus (Alvarez V. et al., 2000); ${ }^{(5)}$ maximum phosphate adsorption (Olsen \& Watanabe, 1957).

unknown molecular mass, they were applied in amounts of $0.0,0.75,1.5,3.0,6.0$, and $12.0 \mathrm{~g} \mathrm{~kg}^{-1}$, corresponding to the application of $0,5,10,20$, 40 , and $80 \mathrm{t} \mathrm{ha}^{-1}$ of an organic compost containing $400 \mathrm{~g} \mathrm{~kg}^{-1}$ water (Andrade et al., 2007). The humic acid contained $568.9 \mathrm{~g} \mathrm{~kg}^{-1}$ carbon and $31.2 \mathrm{~g} \mathrm{~kg}^{-1} \mathrm{~N}$. For standardization, the organic acid rates were labeled $0,1,2,3$, and 4 , respectively. The studies were carried out under laboratory conditions at controlled temperature $\left(25 \pm 2{ }^{\circ} \mathrm{C}\right)$.

\section{Experiment of organic acid mineralization}

The experiment in a $2 \times 3 \times 5$ factorial design evaluated two soils (LV and LVA) $x$ three acids (citric acid - CA, acetic acid - AA and humic acid - HA) $x$ five rates, in a completely randomized design with three replications.

The mineralizable $\mathrm{C}$ was quantified based on $\mathrm{C}$ $\mathrm{CO}_{2}$ emissions captured in a solution of $0.5 \mathrm{~mol} \mathrm{~L}^{-1}$ $\mathrm{NaOH}$, as described by Anderson (1982). Ten milliliter of $0.5 \mathrm{~mol} \mathrm{~L}^{-1} \mathrm{NaOH}$ solution were filled into plastic pots of $50 \mathrm{~mL}$, which were placed in $250 \mathrm{~mL}$ pots. These larger pots were tightly shut to capture the released $\mathrm{C}-\mathrm{CO}_{2}$ and were opened at the moment of exchanging the $\mathrm{NaOH}$ solutions (after 4, 8, 12, 21, and 30 days) (30-day experiment).

To quantify of C- $\mathrm{CO}_{2}$ production, $\mathrm{NaOH}$ solutions were transferred to a $125 \mathrm{~mL}$ Erlenmeyer, to which $10 \mathrm{~mL}$ of $0.25 \mathrm{~mol} \mathrm{~L}^{-1} \mathrm{BaCl}_{2}$ and two or three drops of $1 \%$ phenolphthalein were added. Titration was performed with $0.5 \mathrm{~mol} \mathrm{~L}^{-1} \mathrm{HCl}$ solution.

Since the C-CO $\mathrm{CO}_{2}$ values were found to be high in the first four days of incubation, another similar experiment was carried out. In this latter, the $\mathrm{NaOH}$ solutions were exchanged at shorter intervals (after 24, 48, 72 and $96 \mathrm{~h}$ ), in a 4-day experiment.

The results were subjected to variance analysis, and the qualitative effects were partitioned into contrasts, whereas the $\mathrm{C}-\mathrm{CO}_{2}$ production curve (accumulated $\mathrm{C}-\mathrm{CO}_{2}$ production) over the incubation period was fit to the logistic equation $\mathrm{y}=a / 1+e^{-(\mathrm{b}+\mathrm{cx})}$, where the coefficient $a$ is the saturation curve associated to the maximum $\mathrm{C}-\mathrm{CO}_{2}$ production and indicates the amount of the most easily mineralizable $\mathrm{C} ; b$ indicates the horizontal displacement of the curve (the higher its value the longer will be the time needed to reach saturation); and the $c$ coefficient is related to the growth rate of the function and directly associated to $\mathrm{C}$ lability in the organic matter. Based on these coefficients, it was possible to estimate the time required until the $\mathrm{C}-\mathrm{CO}_{2}$ production is reduced to half of its maximum $\left(t^{1 / 2}\right)$.

\section{Experiment of organic acid adsorption}

The experiment was based on a factorial design 2 x $2 \times 5 \times 4$, corresponding to: two soils (LV and LVA) $\mathrm{x}$ two acids (acetic acid - AA and citric acid - CA) $\mathrm{x}$ five rates $\left(0,1,2,4\right.$, and $\left.8 \mathrm{mmol} \mathrm{dm}^{-3}\right) \mathrm{x}$ four incubation periods $(6,24,48$, and $72 \mathrm{~h})$, and was evaluated in a completely randomized design, with three replications.

This experiment was carried out simultaneously with the one previously described. The incubation periods $(6,24,48$, and $72 \mathrm{~h}$ after beginning the experiment) were determined according to the time of exchange of the $\mathrm{NaOH}$ solutions, to verify the dynamics of organic acid mineralization in a shorter period.

The organic acids were extracted after each incubation period using: ultrapure water (conductivity $<0.1 \mu \mathrm{S} \mathrm{cm}-1$ at $25{ }^{\circ} \mathrm{C}$ ) and $\mathrm{NaOH}$ solution $\left(25 \mathrm{mmol} \mathrm{L}^{-1}\right)$, which represent the fractions in the soil solution and the poorly adsorbed (labile) fractions, respectively. Five grams of soil were placed in centrifuge tubes, to which $10 \mathrm{~mL}$ extractor solution $\left(\mathrm{H}_{2} \mathrm{O}\right.$ and $\left.\mathrm{NaOH}\right)$ were added, and the tubes shaken for $16 \mathrm{~h}$ at $110 \mathrm{rpm}\left(4^{\circ} \mathrm{C}\right)$. After this period, the material was centrifuged at 3,000 rpm for $15 \mathrm{~min}$. and the supernatant filtered through a membrane (pore size $0.45 \mu \mathrm{m}$ ), whereas the organic acids and $\mathrm{P}$ content were assessed by ion chromatography (Silva et al., 2001).

The data were subjected to analysis of variance and the effects on the qualitative factors were partitioned into contrasts, whereas regression models were fit to the quantitative factor. Statistical analyses were carried out using software SAEG-5.0 (UFV, 1993).

\section{RESULTS AND DISCUSSION}

\section{0-day experiment}

During the long incubation period (30 days), the $\mathrm{C}-\mathrm{CO}_{2}$ production varied considerably, evidencing differences between soils (LV and LVA) and organic 
acids (Table 2). The comparison of the organic acids with higher lability (CA and AA) showed that the accumulated $\mathrm{C}-\mathrm{CO}_{2}$ emission from both soils was higher with CA application (C1, Table 3). This result may be related to the higher amount of $\mathrm{C}$ in the $\mathrm{CA}$ molecule (6) than AA (2), corresponding to a higher amount of labile $\mathrm{C}$, making a greater increase in microbial activity possible. In addition, the CA adsorption by soil colloids may promote a displacement to the solution of the previously adsorbed labile $\mathrm{C}$ fractions, and the toxicity effect of the acetic acid may limit biodegradation. The monocarboxylic organic acids, e.g., acetic and propionic, can have a negative effect (toxic) on biodegradation, especially at high concentrations (> $10 \mathrm{mmol} \mathrm{L}^{-1}$ ) (Lineaweaver et al., 1985; Kwon et al., 1997).

Table 2. Accumulated $\mathrm{C}-\mathrm{CO}_{2}$ production in a 30- and a 4-day experiment for acetic (AA), citric (CA) and humic acids (HA) in Rhodic Haplustox (LV) and Typic Haplustox (LVA)

\begin{tabular}{|c|c|c|c|c|c|c|}
\hline \multirow{2}{*}{$\operatorname{Dose}^{(1)}$} & \multicolumn{3}{|c|}{$\mathbf{L V}$} & \multicolumn{3}{|c|}{ LVA } \\
\hline & $\mathbf{A A}$ & CA & HA & $\mathbf{A A}$ & CA & HA \\
\hline & \multicolumn{6}{|c|}{ - $\mathrm{g} \mathrm{kg}^{-1}$ soil } \\
\hline & \multicolumn{6}{|c|}{ 30-day experiment } \\
\hline 0 & 3.13 & 2.88 & 3.11 & 5.70 & 6.16 & 5.68 \\
\hline 1 & 3.50 & 3.33 & 3.20 & 6.33 & 7.28 & 5.91 \\
\hline 2 & 3.59 & 3.97 & 3.32 & 6.41 & 7.26 & 6.03 \\
\hline 3 & 3.70 & 4.72 & 3.50 & 6.40 & 7.93 & 6.20 \\
\hline 4 & 3.66 & 5.79 & 3.64 & 6.58 & 9.25 & 6.86 \\
\hline \multirow[t]{2}{*}{$\overline{\mathrm{x}}$ acid } & 3.52 & 4.14 & 3.35 & 6.28 & 7.58 & 6.14 \\
\hline & \multicolumn{6}{|c|}{ 4-day experiment } \\
\hline 0 & 1.23 & 1.03 & 1.09 & 2.89 & 3.21 & 3.02 \\
\hline 1 & 1.38 & 1.79 & 0.74 & 3.15 & 4.02 & 3.25 \\
\hline 2 & 1.10 & 2.56 & 0.79 & 3.31 & 4.82 & 3.00 \\
\hline 3 & 1.43 & 2.29 & 0.73 & 3.29 & 5.45 & 2.55 \\
\hline 4 & 2.29 & 3.65 & 0.81 & 3.38 & 6.61 & 2.63 \\
\hline$\overline{\mathrm{x}}$ acid & 1.47 & 2.26 & 0.71 & 3.20 & 4.82 & 2.89 \\
\hline
\end{tabular}

${ }^{(1)}$ Rates $0,1,2,3$, and 4 correspondence to $0 ; 1 ; 2 ; 4$; and $8 \mathrm{mmol}$ $\mathrm{dm}^{-3}$ for AA and CA; and $0 ; 1,5 ; 3 ; 6$ and $12 \mathrm{~g} \mathrm{~kg}^{-1}$ for HA, respectively. AA: acetic acid; CA: citric acid; HA: humic acid.

Table 3. Contrast comparing the effect of the rates and incubation period within each soil (LV and LVA) for accumulated $\mathrm{C}-\mathrm{CO}_{2}$ production in a 30- and a 4-day experiment

\begin{tabular}{cccccc}
\hline \multirow{2}{*}{ Contrast } & \multicolumn{2}{c}{ 30-day experiment } & & \multicolumn{2}{c}{ 4-day experiment } \\
\cline { 2 - 3 } \cline { 5 - 6 } & LVA & LV & & LVA & LV \\
\hline $\mathrm{C} 1$ & $0.62^{* *}$ & $1.30^{* *}$ & & $0.79^{* *}$ & $1.62^{* *}$ \\
$\mathrm{C} 2$ & $0.17^{*}$ & $0.14^{*}$ & & $0.76^{* *}$ & $0.31^{* *}$ \\
\hline
\end{tabular}

$\mathrm{C} 1$ = CA - AA; C2 = AA - HA; AA: acetic acid; CA: citric acid; HA: humic acid; LVA: Typic Haplustox; LV: Rhodic Haplustox. * and ** significant at 0.05 and 0.01 , respectively, by the $\mathrm{F}$ test.
According to Marschner \& Kalbitz (2003), based on the microbial absorption mechanism, it might be expected that smaller molecules would be preferentially mineralized. For those authors, however, other characteristics should be considered, such as: chemical structure, toxicity degree, complexation power, enzymatic inhibition, aside from soil properties such as adsorption capacity, texture and $\mathrm{pH}$. In this sense, Strom et al. (2001) studied calcareous soil and observed higher resistance of oxalic acid to biodegradation, than of citric and malic acids, due to the formation of $\mathrm{Ca}$ oxalate precipitate, which increased the protection against the microbial activity.

In a comparison of AA with $\mathrm{HA}$ (C2, Table 3), higher values of accumulated $\mathrm{C}-\mathrm{CO}_{2}$ production were observed for $\mathrm{AA}$, both for LVA and LV, reflecting its high lability in relation to HA. According to Qualls (2004), only $12.7 \%$ of the total amount of HA applied to the soil was mineralized within one year, with a half-life time of 10 years. Some characteristics such as the chemical composition, quantity and quality of the functional groups and molecular structure are the causes of the inherent resistance of HA to biodegradation (Qualls, 2004).

The differences in accumulated $\mathrm{C}-\mathrm{CO}_{2}$ production between AA and HA were not as marked as the clear difference in lability. The long incubation period (30 days) contributed a dilution of the AA effect, relative to HA, as shown by the 4-day experiment. According to van Hees et al. (2005), LOAs can be quickly mineralized, with the half-life time from 0.5 to $12 \mathrm{~h}$. These results reinforce the possibility of a dilution effect of the $\mathrm{C}-\mathrm{CO}_{2}$ production in the AA treatments, over time. The following order was observed for the increased $\mathrm{C}-\mathrm{CO}_{2}$ production in the soils under study: $\mathrm{CA}>\mathrm{AA}>\mathrm{HA}$.

The accumulated $\mathrm{C}-\mathrm{CO}_{2}$ production was adequately adjusted to the logistic growth function, for all treatments $(\mathrm{p}<0.01)\left(\right.$ Table 4). The highest values for $\mathrm{C}-\mathrm{CO}_{2}$ production ( $a$ coefficient) were observed for $\mathrm{CA}$, therefore indicating that this acid has qualitative characteristics that favored its decomposition and/or a higher proportion of easily mineralizable $\mathrm{C}$ in both LVA and LV. In this sense, AA was shown to be superior to HA.

Higher values of the $b$ coefficient (longer time to reach $\mathrm{C}-\mathrm{CO}_{2}$ saturation) were observed for the treatment with HA in the LVA, reflecting its higher recalcitrance, unlike in the $L V$. The sample preparation may have led to these results. Thus, the sieving of the soil samples through $1 \mathrm{~mm}$ sieve caused the breakdown of the macroaggregates, exposing a high amount of chemically and physically protected organic material (Oades, 1984; van Veen et al., 1985; Ladd et al., 1993; Hassink \& Whitmore, 1997). This effect was only verified for $L V$ due to the higher values of organic $\mathrm{C}$ than in LVA (Table 1). No differences were observed between AA and CA for this coefficient. The long incubation period (30 days) probably minimized the differences. 
A low variation in the growth rates of the function (c coefficient) was observed for both LVA and LV, suggesting that these rates were less sensitive to the qualitative variations of the acids under study (Table 4). This fact apparently induced the same growth pattern of the curve.

The highest values of $t 1 / 2$ found for HA in LVA corroborated the slower mineralization rate of this organic material. When analyzing $\mathrm{LV}$, however, a differentiated effect was observed in $\mathrm{t}^{1} 1 / 2$ values. Higher $\mathrm{t} 1 / 2$ values were found for $\mathrm{CA}$, indicating that this acid mineralizes at a lower rate, i.e., it is less labile. Nevertheless, this lower mineralization rate could also be related to the strong interaction of CA with the soil mineral fraction, as demonstrated in the adsorption experiment. Adsorption significantly reduces the mineralization rates of LOAs (Boudot, 1992; Jones \& Edwards, 1998) and is considered important as stabilizing process of these acids in the soil (Marschner $\&$ Kalbitz, 2003). No effect was observed for AA, due to its low affinity for the soil adsorption sites. van Hees et al. (2003b) observed that about $65 \%$ of the $\mathrm{CA}$ applied was mineralized after $72 \mathrm{~h}$ in the $\mathrm{E}$ horizon, but only $3 \%$ in samples of the B horizon. These authors reported that the higher adsorption capacity in the B-horizon samples strongly affected the mineralization rate of $\mathrm{CA}$.

\section{4-day experiment}

A great similarity was observed between the results of the 4- and the 30- day experiment (Table 2). However, the differences in lability between the

Table 4. Coefficient of the logistic equation and time required until the $\mathrm{C}-\mathrm{CO}_{2}$ production is reduced to half of its maximum $\left(t_{1 / 2}=-b / c\right)$ for the organic acids for (AA, CA and HA) for Rhodic Haplustox (LV) and Typic Haplustox (LVA) in a 30 and a 4-day experiment

\begin{tabular}{|c|c|c|c|c|c|c|c|c|c|c|c|c|c|}
\hline \multirow{2}{*}{$\operatorname{Dose}^{(1)}$} & \multicolumn{3}{|c|}{$\mathbf{a}^{(2)}$} & \multicolumn{3}{|c|}{$\mathbf{b}^{(2)}$} & \multicolumn{3}{|c|}{$\mathbf{c}^{(2)}$} & \multicolumn{4}{|c|}{ t $1 / 2(h)$} \\
\hline & AA & CA & HA & $\mathbf{A A}$ & CA & HA & $\mathbf{A A}$ & CA & HA & $\mathbf{R}^{2}$ & AA & CA & HA \\
\hline & \multicolumn{13}{|c|}{ 30-day experiment } \\
\hline & \multicolumn{13}{|c|}{ LVA } \\
\hline 0 & 3.45 & 3.29 & 3.40 & -0.31 & -0.37 & -0.41 & 0.07 & 0.06 & 0.07 & 0.99 & 4.43 & 6.17 & 5.86 \\
\hline 1 & 3.78 & 4.23 & 3.38 & -0.17 & -0.10 & -0.44 & 0.08 & 0.06 & 0.09 & 0.99 & 2.13 & 1.67 & 4.89 \\
\hline 2 & 4.03 & 4.61 & 3.56 & -0.05 & -0.01 & -0.38 & 0.07 & 0.05 & 0.08 & 0.99 & 0.71 & 0.14 & 4.75 \\
\hline 3 & 4.21 & 4.22 & 3.98 & -0.11 & -0.19 & -0.25 & 0.07 & 0.07 & 0.07 & 0.98 & 0.14 & 2.71 & 3.57 \\
\hline 4 & 3.87 & 5.08 & 4.02 & -0.07 & -0.16 & -0.27 & 0.09 & 0.12 & 0.06 & 0.99 & 0.78 & 1.33 & 4.50 \\
\hline & & & & & & & $\mathrm{LV}$ & & & & & & \\
\hline 0 & 6.10 & 6.83 & 6.05 & -0.26 & -0.22 & -0.17 & 0.10 & 0.10 & 0.10 & 0.99 & 2.60 & 2.20 & 1.70 \\
\hline 1 & 6.76 & 8.54 & 6.24 & -0.30 & -0.46 & -0.33 & 0.10 & 0.08 & 0.11 & 0.98 & 3.00 & 5.75 & 3.00 \\
\hline 2 & 6.71 & 8.22 & 6.42 & -0.35 & -0.37 & -0.36 & 0.12 & 0.09 & 0.11 & 0.98 & 2.92 & 5.22 & 3.27 \\
\hline 3 & 6.66 & 9.06 & 6.61 & -0.31 & -0.33 & -0.41 & 0.12 & 0.09 & 0.11 & 0.99 & 2.58 & 5.44 & 3.73 \\
\hline \multirow[t]{3}{*}{4} & 6.73 & 9.96 & 7.36 & -0.38 & -0.41 & -0.52 & 0.14 & 0.10 & 0.11 & 0.99 & 2.71 & 4.10 & 4.72 \\
\hline & \multicolumn{13}{|c|}{ 4-day experiment } \\
\hline & \multicolumn{13}{|c|}{ LVA } \\
\hline 0 & 1.28 & 1.11 & 1.01 & -4.07 & -3.67 & -4.11 & 0.08 & 0.08 & 0.06 & 0.99 & 50.88 & 45.88 & 58.71 \\
\hline 1 & 1.45 & 1.80 & 0.85 & -5.10 & -3.24 & -7.93 & 0.08 & 0.14 & 0.05 & 0.99 & 63.75 & 23.14 & 158.6 \\
\hline 2 & 1.16 & 2.65 & 0.91 & -4.81 & -3.95 & -6.46 & 0.08 & 0.10 & 0.05 & 0.98 & 60.13 & 39.50 & 129.2 \\
\hline 3 & 1.49 & 2.70 & 0.84 & -5.31 & -3.47 & -5.53 & 0.09 & 0.09 & 0.05 & 0.99 & 59.00 & 38.56 & 110.6 \\
\hline \multirow[t]{2}{*}{4} & 2.68 & 4.21 & 0.95 & -4.75 & -3.38 & -4.54 & 0.08 & 0.07 & 0.05 & 0.99 & 59.38 & 48.29 & 90.80 \\
\hline & & & & & & & $\mathrm{LV}$ & & & & & & \\
\hline 0 & 3.35 & 3.66 & 3.19 & -4.12 & -4.05 & -4.20 & 0.07 & 0.06 & 0.07 & 0.99 & 58.86 & 67.50 & 60.00 \\
\hline 1 & 4.06 & 4.49 & 3.47 & -3.65 & -4.23 & -4.02 & 0.06 & 0.07 & 0.05 & 0.99 & 60.83 & 60.43 & 80.40 \\
\hline 2 & 3.99 & 5.55 & 3.72 & -3.30 & -3.82 & -4.34 & 0.06 & 0.08 & 0.05 & 0.99 & 55.00 & 47.75 & 86.80 \\
\hline 3 & 3.84 & 5.83 & 3.70 & -4.31 & -3.93 & -5.17 & 0.08 & 0.07 & 0.05 & 0.99 & 53.88 & 56.14 & 103.4 \\
\hline 4 & 3.69 & 7.02 & 3.67 & -4.57 & -3.89 & -5.15 & 0.08 & 0.08 & 0.05 & 0.99 & 57.13 & 48.63 & 103.0 \\
\hline
\end{tabular}

(1) Rates of $0,1,2,3$, and 4 corresponding to $0 ; 1 ; 2 ; 4$; and $8 \mathrm{mmol} \mathrm{dm}^{-3}$ for AA and CA; and $0 ; 1,5 ; 3 ; 6$; and $12 \mathrm{~g} \mathrm{~kg}^{-1}$ for $\mathrm{HA}_{\text {, }}$ respectively. AA: acetic acid; CA: citric acid; HA: humic acid; LVA: Typic Haplustox; LV: Rhodic Haplustox. ${ }^{(2)}$ Logistic equation $\mathrm{y}=\mathrm{a} /\left(1+\mathrm{e}^{-(\mathrm{b}+\mathrm{cx})}\right), a$ coefficient: indicates the most easily mineralizable amount of $\mathrm{C} ; b$ coefficient: indicates the horizontal displacement of the curve, and the higher its value, the longer is the time required to reach saturation; $c$ coefficient: directly associated to $\mathrm{C}$ lability in the organic matter; and $\mathrm{t} 1 / 2$ : estimate the time required until $\mathrm{C}^{-\mathrm{CO}_{2}}$ production is decreased to half of its maximum. 
organic acids were rather evident. The results of the 4-day experiment showed the differences in lability between the studied acids (AA and CA vs HA) more clearly than those of the 30-day experiment, particularly in the LVA soil (Table 2).

Since LV is a clayey soil with high organic matter content (Table 1), it is believed that the disruption of the aggregates by the sieving of the soil (mesh $1 \mathrm{~mm}$ ) and the consequent release of the protected organic matter (Ladd et al., 1993; Hassink \& Whitmore, 1997; Conteh \& Blair, 1998) contributed to masking the effect of the acids. The sequence for the increase of the $\mathrm{C}-\mathrm{CO}_{2}$ production in the soils $(\mathrm{CA}>\mathrm{AA}>\mathrm{HA})$ did not differ from the results of the 30 -day experiment (Table 3).

In this experiment, the accumulated $\mathrm{C}-\mathrm{CO}_{2}$ production in all treatments was adequately adjusted to the logistic growth function $(\mathrm{p}<0.01)$ (Table 4). According to the results obtained in the 30-day experiment, the highest values associated to the maximum $\mathrm{C}-\mathrm{CO}_{2}$ production ( $a$ coefficient) were observed for CA, followed by AA and HA, in both LVA and LV (Table 4).

The greatest differences between the two experiments are related to the coefficients $b$ and $c$ (Table 4). By the shorter time interval between the measurements of $\mathrm{C}-\mathrm{CO}_{2}$ production in the 4-day experiment ( $24 \mathrm{~h}$ ) than in the 30 -day experiment (30 days), it was possible to evaluate the differences in lability between the acids (coefficients $b$ and $c$, Table 4) with greater sensitivity.

The $b$ coefficient, which is directly related to the time needed to reach $\mathrm{C}-\mathrm{CO}_{2}$ saturation was consistently higher for HA, in both LVA and LV, confirming its more recalcitrant nature in relation to the other acids (Table 4). For the most labile group (AA and CA), this coefficient was lowest for CA.

The short (4-day) incubation period of this experiment provided variation in the growth rate of the function (c coefficient) (Table 4). These variations were more marked for LVA than LV, probably due to the lower effect of sieving and release of protected organic matter in the LVA.

The coefficient $c$ fore CA was higher than of the other acids, indicating its higher lability, indicated by the lowest of $\mathrm{t} 1 / 2$, for both LVA and LV. The $c$ coefficient for HA was lowest and the $t \frac{1}{2}$, highest, reinforcing its slower mineralization rates.

\section{Soil organic acid adsorption}

The application of organic acids at different rates and incubation periods generally affected the levels extracted by $\mathrm{H}_{2} \mathrm{O}$ (soluble fraction) (Figure 1) and by $\mathrm{NaOH}$ (labile fraction) (Figure 2) as well as the $\mathrm{P}$ concentration (Figures 1 and 2), in the different soils.

Regardless of the extractant, higher AA than CA levels were extracted. These differences reflect the characteristics of the organic acids under study. Citric acid has a higher amount of carboxylic groups that participate in the soil adsorption reactions, which explains the lowest extracted levels by both water and $\mathrm{NaOH}$. Jones \& Edwards (1998) studied the adsorption and biodegradation of CA and glucose and found an adsorbed amount of 99,83 and $70 \%$ of the applied amount of CA (500 $\left.\mathrm{mmol} \mathrm{L}^{-1}\right)$, when using $\mathrm{Fe}(\mathrm{OH})_{3}$, kaolinite and $\mathrm{B}$ horizon samples, respectively. In the subsurface horizons, containing higher contents of $\mathrm{Fe}$ and $\mathrm{Al}$ oxides, the amount of organic acids such as citrate adsorbed to the surface of minerals may be 3,000 times higher than that in the soil solution (van Hees et al., 2003a). The soil adsorption capacity has a buffering effect, maintaining the concentration of those acids in the soil solution low. This could explain why higher amounts in $\mathrm{C}-\mathrm{CO}_{2}$ production were accumulated by $\mathrm{CA}$ in the mineralization experiment (Tables 2). The concentration in the soil solution is therefore lower than of the other acids (Figures 1 and 2).

The adsorption of organic acids is usually reversible, which would lead to their gradual return to the soil solution, making them bioavailable again (Marschner \& Kalbitz, 2003). This can be observed by the decrease in the concentration of the poorly adsorbed $\mathrm{P}$ that would probably be transformed to less labile forms with a more stable binding to soil colloids (Gonçalves et al., 1985; Novais \& Smyth, 1999) throughout the incubation period, but without a consequent increase in CA concentration in the solution (Figures 1 and 2). Phosphorus is readsorbed by the soil, displacing the CA that changes to the solution where it is biodegraded, which would induce no increase in the $\mathrm{P}$ concentration in the solution.

The lower affinity of AA to soil adsorption sites can be verified by a similar behavior when using the extractors $\mathrm{H}_{2} \mathrm{O}$ and $\mathrm{NaOH}$ during the incubation period (Figures 1 and 2). The values of AA extracted by $\mathrm{H}_{2} \mathrm{O}$ (water-soluble fraction) did not differ from values extracted by the extractor $\mathrm{NaOH}$ (soluble fraction plus the fraction of weakly adsorbed AA to the mineral surface). For AC, the highest values for the extractor $\mathrm{NaOH}$ indicate a more specific interaction with the adsorption sites of the minerals.

The great affinity of CA to the soil adsorption sites was evidenced by the increase of $\mathrm{P}$ concentration in solution in relation with the increase of the applied $\mathrm{CA}$ rate (Figures 1 and 2). At increasing CA rates, the competition for adsorption sites is also increased (Stevenson, 1994), leading to $\mathrm{P}$ desorption and a consequent increase of $\mathrm{P}$ levels in the solution. Andrade et al. (2003) evaluated the effect of the competitive adsorption of organic acids and $\mathrm{P}$ in Oxisol for $16 \mathrm{~h}$. In the CA treatment, a maximum adsorption reduction of 100 and $36 \%$ were observed for LVA and $\mathrm{LV}$, respectively. These results explain the high values of $\mathrm{P}$ extracted by $\mathrm{H}_{2} \mathrm{O}$ and $\mathrm{NaOH}$ (Figures 1 and 2), mainly in the 24-h period. According to Earl et al. 
(1979), the effect of acetic acid on the competition for soil adsorption sites as well as on the efficiency of $\mathrm{P}$ desorption is negligible. The lowest affinity for adsorption sites of AA is in agreement with the lowest values found for $\mathrm{P}$ in solution (Figures 1 and 2).
It is worth emphasizing the effect of organic acids such as CA on the increased $P$ availability to the plants. Although the $\mathrm{P}$ concentration was drastically reduced after $72 \mathrm{~h}$ (Figures 1 and 2), the presence of these organic acids in the soil
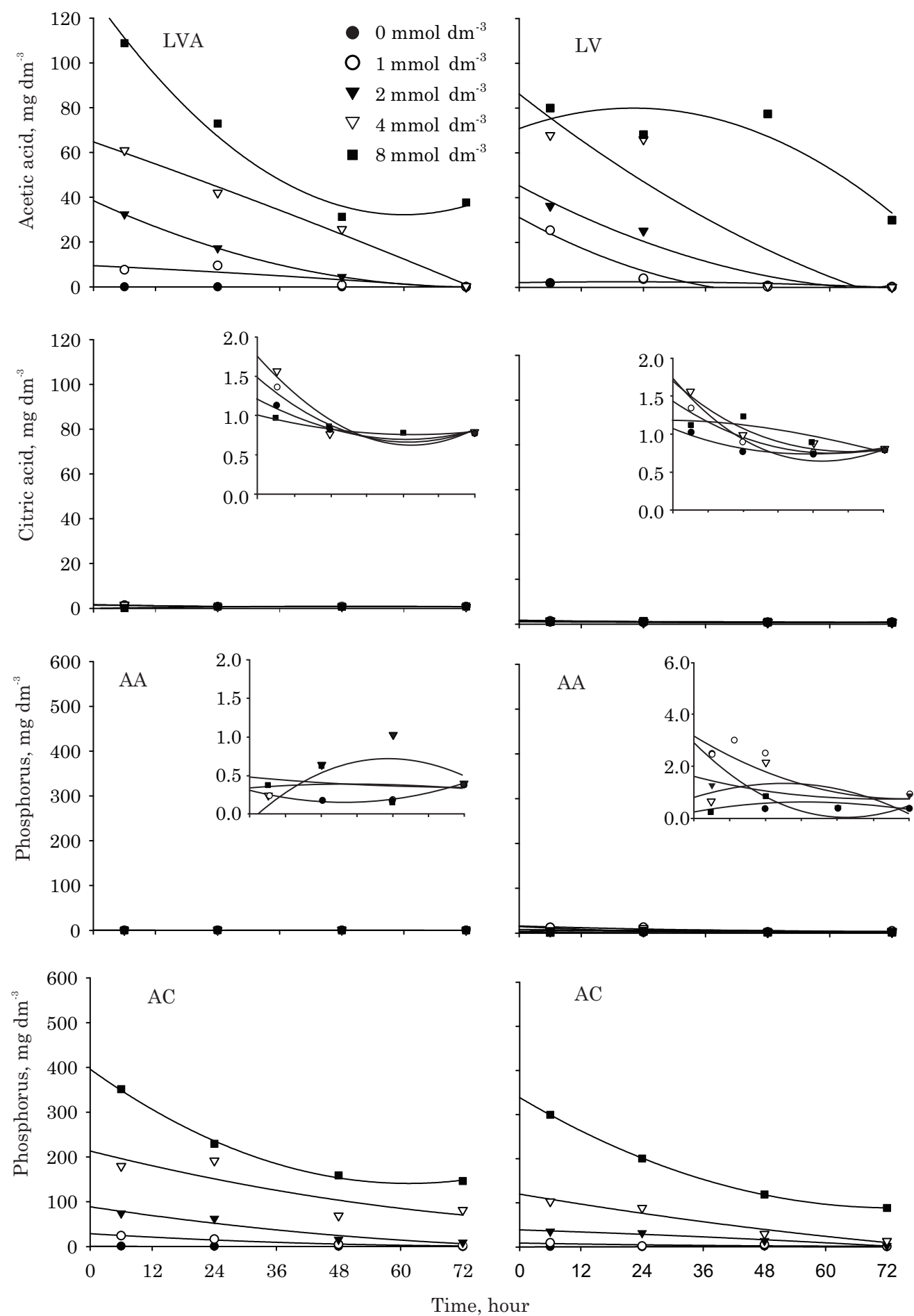

Figure 1. Effect of incubation time (hours) and rates of organic acids on the concentration of acetic (AA) and citric acid (AC) and phosphorus, extracted by $\mathrm{H}_{2} \mathrm{O}$, in Rhodic Haplustox (LV) and Typic Haplustox (LVA). 
solution due to root exudation, microbial metabolism and soil management systems that contribute to increased soil organic matter, for example, maintain this blockage process of the adsorption site for a longer period of time, increasing $\mathrm{P}$ availability in the soil.
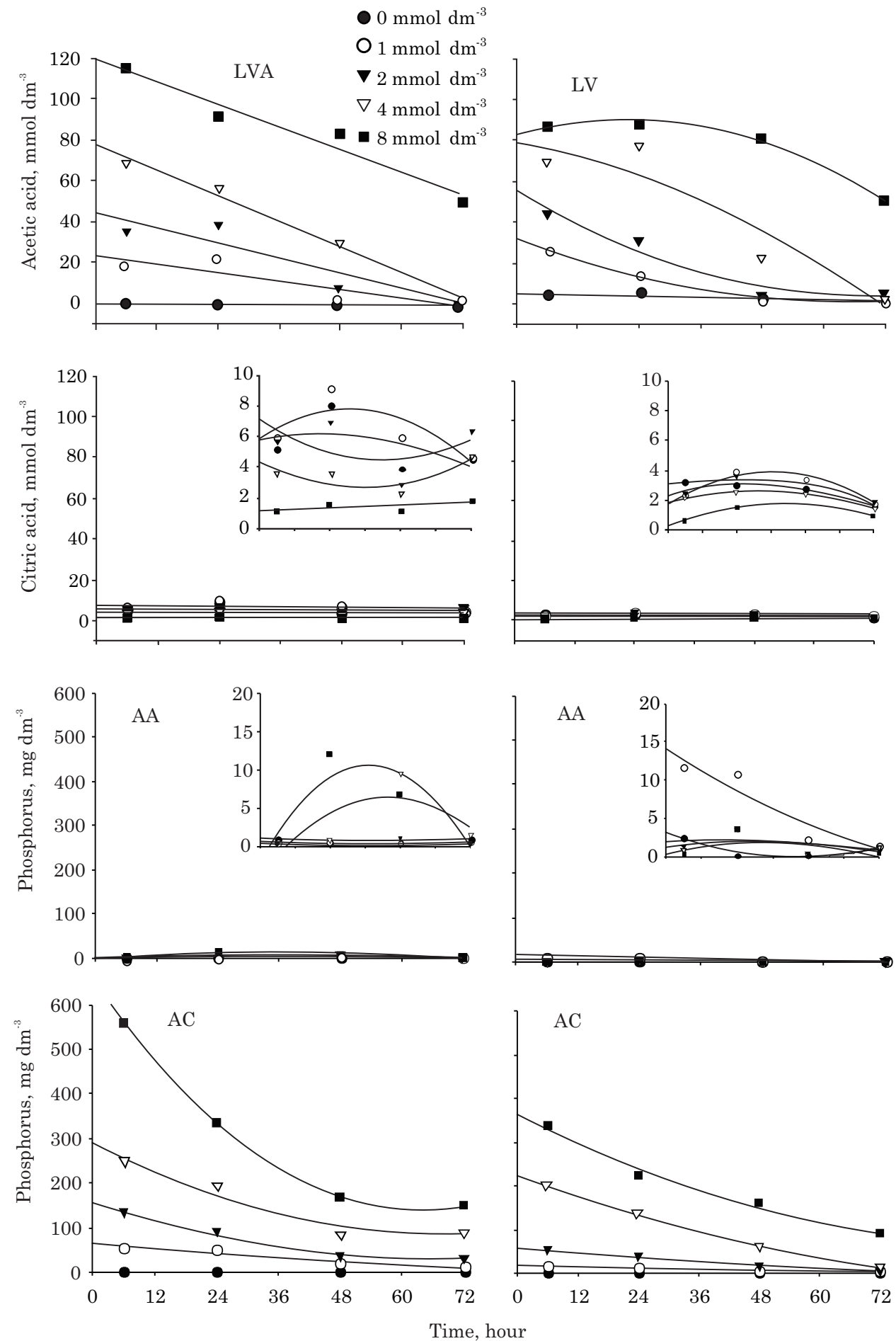
important mechanism by which the bioavailability and biodegradation capacity of the microbial biomass can be reduced (Jones \& Edwards, 1998). The time scale of the protection process is totally dependent on the acid characteristics and the soil properties.
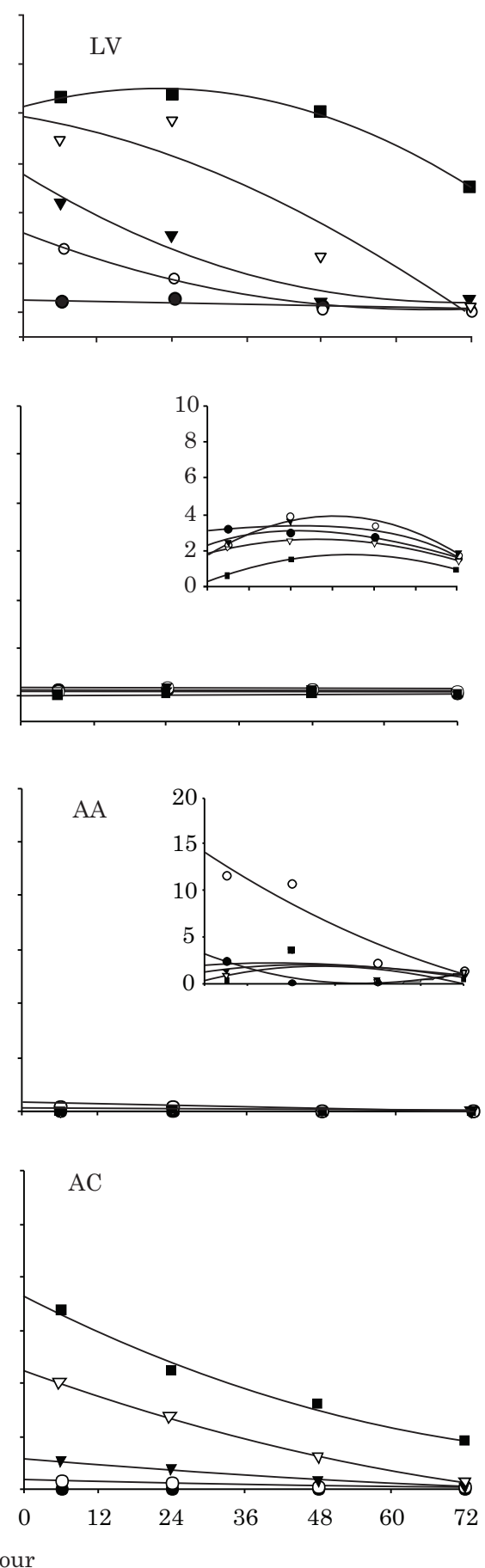

Figure 2. Effect of incubation time (hours) and rates of organic acids on the concentration of acetic (AA) and citric acid (AC) and phosphorus, extracted by NaOH, in Rhodic Haplustox (LV) and Typic Haplustox (LVA). 


\section{CONCLUSIONS}

1. The application of organic acid to the soils promoted an increase in $\mathrm{C}-\mathrm{CO}_{2}$ production, following the order: $\mathrm{CA}>\mathrm{AA}>\mathrm{HA}$.

2 . The results of the 4-day experiment showed the differences in lability between the acids in more detail than those of the 30-day experiment.

3. The soil adsorption capacity may constitute an important mechanism in reducing the mineralization of the studied acids. The period of action of this mechanism depends on the acid and soil properties. CA has a higher affinity to the soil adsorption sites than AA.

\section{ACKNOWLEDGEMENT}

This work was supported by the National Council of Science and Technology (CNPq).

\section{LITERATURE CITED}

ALVAREZ V, V.H. \& RIBEIRO, A.C. Calagem. In: RIBEIRO, A.C.; GUIMARÃES, P.T.G. \& ALVAREZ V., V.H., eds. Recomendações para o uso de corretivos e fertilizantes em Minas Gerais - $5^{\text {a }}$ aproximação. Viçosa, MG, 1999. p.43-60.

ALVAREZ V., V.H.; NOVAIS, R.F.; DIAS, L.E. \& OLIVEIRA, J.A. Determinação e uso de fósforo remanescente. Bol. Inf. SBCS, 52:27-32, 2000.

ANDERSON, J.P.E. Soil respiration. In: PAGE, A.L.; MILLER, R.H. \& KEENEY, D.R., eds. Methods of soil analysis. Madison, SSSA, 1982. Part 2. p.831-866.

ANDRADE, F.V.; MENDONÇA, E.S.; ALVAREZ V., V.H. \& NOVAIS, R.F. Adição de ácidos orgânicos e húmicos em Latossolos e adsorção de fosfato. R. Bras. Ci. Solo, 27:10031011, 2003.

ANDRADE, F.V.; MENDONÇA, E.S.; SILVA, I.R. \& MATEUS, R.F. Dry matter production and phosphorus accumulation by maize plants in response to the addition of organic acids in oxisols. Commun. Soil Sci. Plant Anal., 38:27332745, 2007.

BOUDOT, J.P. Relative efficiency of complexed aluminium, noncrystalline $\mathrm{Al}$ hydroxide, allophane and imogolite in retarding the biodegradation of citric acid. Geoderma, 52:29-39, 1992.

CONTEH, A. \& BLAIR, G.J. The distribution and relative losses of soil organic carbon fractions in aggregate size fractions from cracking clay soil (Vertisols) under cotton production. Aust. J. Soil Res., 36:257-271, 1998.

EARL, K.D.; SYERS, J.K. \& McLAUGHLIN, J.R. Origin of the effects of citrate, tartarate, and acetate on phosphate sorption by soils and synthetic gels. Soil Sci. Soc. Am. J., 43:674-678, 1979.
GAHOONIA, T.S.; ASMAR, F.; GIESE, H.; GISSEL-NIELSEN, G. \& NIELSEN, N.E. Root-released organic acids and phosphorus uptake of two barley cultivars in laboratory and field experiments. Eur. J. Agric., 12:281-289, 2000.

GONÇALVES, J.L.M.; FIRME, D.J.; NOVAIS, R.F. \& RIBEIRO, A.C. Cinética de adsorção de fósforo em solos de cerrado. R. Bras. Ci. Solo, 9:107-111, 1985.

HASSINK, J. \& WHITMORE, A.P. A model of the physical protection of organic matter in soils. Soil Sci. Soc. Am. J., 61:131-139, 1997.

JONES, D.L. \& DARRAH, P.R. Role of root derived organic acids in the mobilization of nutrients from the rhizosphere. Plant Soil, 166:247-257, 1994.

JONES, D.L. Organic acids in the rhizosphere - A critical review. Plant Soil, 205:25-44, 1998.

JONES, D.L. \& BRASSINGTON, D.S. Sorption of organic acids in acid soils and its implications in the rhizosphere. Eur. J. Soil Sci., 49:447-455, 1998.

JONES, D.L. \& EDWARDS, A.C. Influence of sorption on the biological utilization of two simple carbon substrates. Soil Biol. Biochem., 30:1895-1902, 1998.

JONES, D.L.; DENNIS, P.G.; OWEN, A.G. \& van HEES, P.A.W. Organic acid behavior in soils - misconceptions and knowledge gaps. Plant Soil, 248:31-41, 2003.

KENNEDY, A.C. \& SMITH, K.L. Soil microbial diversity and the sustainability of agricultural soils. Plant Soil, 170:7586, 1995.

KWON, Y.M.; SALINAS, J.R.; DURANT, J.A.; NISBET, D.J. \& RICKE, S.C. Volatile fatty acid sensitivity of Veillonella CF3 from a continuous-flow probiotic culture. J. Food Sci., 17:59-67, 1997.

LADD, J.N.; FOSTER, R.C. \& SKJEMSTAD, J.O. Soil structure: Carbon and nitrogen metabolism. Geoderma, 56:401-434, 1993.

LUNDSTROM, U.S.; van BREEMEN, N. \& BAIN, D. The podzolization process. A review. Geoderma, 94:91-107, 2000.

LINEAWEAVER, W.; HOWARD, R.; SOUCY, D.; McMORRIS, S.; FREEMAN, J.; CRAIN, C.; ROBERTSON, J. \& RUMLEY, T. Topical antimicrobial toxicity. Arch. Surg., 120:267-270, 1985.

MARSCHNER, B. \& KALBITZ, K. Controls of bioavailability and biodegradability of dissolved organic matter in soils. Geoderma, 113:211-235, 2003.

NOVAIS, R.F. \& SMYTH, T.J. Fósforo em solo e planta em condições tropicais. Viçosa, MG, Universidade Federal de Viçosa, 1999. 399p.

OADES, J.M. Soil organic matter and structural stability: Mechanisms and implications for management. Plant Soil, 76:319-337, 1984.

OLSEN, S.R. \& WATANABE, F.S. A method to determine a phosphorus adsorption maximum of soils as measured by the Langmuir isotherm. Soil Sci. Soc. Am. Proc., 24:144149, 1957. 
QUALLS, R.G. Biodegradability of humic substances and other fractions of decomposing leaf litter. Soil Sci. Soc. Am. J., 68:1705-1712, 2004.

RAICH, J.W. \& TUFEKCIOGLU, A. Vegetation and soil respiration: Correlations and controls. Biogeochemistry, 48:71-90, 2000.

SILVA, I.R.; SMYTH, T.J.; RAPER, C.D.; CARTER, T.E. \& RUFTY, T.W. Differential aluminium tolerance in soybean: An evaluation of the role of organic acids. Physiol. Plant., 112:200-210, 2001.

STROM, L.; OWEN, A.G.; GODBOLD, D.L. \& JONES, D.L. Organic acid behavior in a calcareous soil: Sorption reactions and biodegradation rates. Soil Biol. Biochem., 33:2125-2133, 2001.

STEVENSON, F.J. Humus chemistry: Genesis, composition, reactions. New York, John Wiley \& Sons, 1994. 443p.

UNIVERSIDADE FEDERAL DE VIÇOSA - UFV. SAEG - Sistema para Análises Estatísticas e Genéticas. (System for statistical and genetic analysis), Versão 5.0. Viçosa, MG, 1993.

van HEES, P.A.W.; JONES, D.L. \& GODBOLD, D.L. Biodegradation of low molecular weight organic acids in forest soils. Soil Biol. Biochem., 34:1261-1272, 2002. van HEES, P.A.W.; VINOGRADOFFB, S.I.; EDWARDS, A.C.; GODBOLD, D.L. \& JONES, D.L. Low molecular weight organic acid adsorption in forest soils: Effects on soil solution concentrations and biodegradation rates. Soil Biol. Biochem., 35:1015-1026, 2003a.

van HEES, P.A.W.; JONES D.L. \& GODBOLD, D.L. Biodegradation of low molecular weight organic acids in a limed forest soil. Water Air Soil Pollut., 3:121-144, 2003b.

van HEES, P.A.W.; JONES, D.L.; FINLAYC, R.; GODBOLD, D.L. \& LUNDSTROM, U.S. The carbon we do not see the impact of low molecular weight compounds on carbon dynamics and respiration in forest soils: A review. Soil Biol. Biochem., 37:1-13, 2005.

van VEEN, J.A.; LADD, J.N. \& AMATO, M. Turnover of carbon and nitrogen through the microbial biomass in a sandy loam and a clay soil incubated with $\left[{ }^{14} \mathrm{C}(\mathrm{U})\right]$ glucose and $\left[{ }^{15} \mathrm{~N}\right]\left(\mathrm{NH}_{4}\right)_{2} \mathrm{SO}_{4}$ under different moisture regimes. Soil Biol. Biochem., 17:747-756, 1985.

YEOMANS, J.C. \& BREMNER, J.M. A rapid and precise method for routine determination of carbon in soil. Commun. Soil Sci. Plant Anal., 19:1467-1476, 1988. 